九州大学学術情報リポジトリ

Kyushu University Institutional Repository

\title{
Impact of Market Liberalization on International Pulses Trade of Myanmar and India
}

Moe, Aung Kyaw

Laboratory of Food Marketing, Division of Industrial Organization of Agribusiness, Department of Agricultural and Resource Economics, Graduate School of Bioresource and Bioenvironmental Sciences, Kyushu University

Yutaka, Tomoyuki

Faculty of Agriculture, Kyushu University

Fukuda, Susumu

Faculty of Agriculture, Kyushu University

Kai, Satoshi

Faculty of Business, Marketing and Distribution, Nakamura Gakuen University

https://doi.org/10.5109/12873

出版情報：九州大学大学院農学研究院紀要. 53 (2)，pp.553-561，2008-10-28. Faculty of Agriculture, Kyushu University

バージョン：

権利関係 : 


\title{
Impact of Market Liberalization on International Pulses Trade of Myanmar and India
}

\author{
Aung Kyaw MOE', Tomoyuki YUTAKA, Susumu FUKUDA*, \\ and Satoshi KAI ${ }^{2}$ \\ Laboratory of Food Marketing, Division of Industrial Organization of Agribusiness, \\ Department of Agricultural and Resource Economics, Faculty of Agriculture, \\ Kyushu University, Fukuoka 812-8581, Japan \\ (Received June 7, 2008 and accepted July 16, 2008)
}

\begin{abstract}
Before 1990, international trade of pulses did not well develop because of trade restrictions in major export and import countries. India and Myanmar are major trade partners of pulses because Myanmar pulses favor consumer preference, low freight charge and fast delivery. There are still major trade restrictions of pulses such as minimum support price program, high levy of import tax and export banning policy in India, and high levy of export tax and misalignment exchange rate system in Myanmar. In Johansen cointegration test, all prices of international markets were weakly integrated in long run. In VECM test, India had negative equilibrium condition in all pulses while Myanmar had positive equilibrium conditions. India could correct the deviation of price in long run equilibrium with 19\% in black gram, 16\% in green gram, and $35 \%$ in pigeon pea, within a month. In Granger causality test, all prices of Myanmar Granger caused India except in black gram. India Granger caused Myanmar black gram price. Myanmar is a leading country for international price formation. But, there was unidirectional causality in international price of pulse. It indicated the monopolistic behavior and asymmetry price transmission in the international markets of pulses. This imperfect and asymmetry price transmission may be the results of quantitative restrictions of trade, misalignment exchange rate system and high levy of export and import taxes in pulses trade.
\end{abstract}

\section{INTRODUCTION}

All domestic markets are closely related to international food markets. These connections influence on the formation of price of domestic and international markets. Although domestic policies of food and agriculture emphasize only on national objectives and concerns, these policies impact on international agriculture including production, consumption and trade. Governments intervene in the agriculture sector for many reasons such as price and income enhancement for producers, subsidization of consumer prices, implicit and explicit taxation of the sector, transfers of income and many others. These interventions can alter not only the connections of domestic to international markets, but also the linkages of markets of other countries.

World markets are distorted by tariffs, taxes and subsidies of agricultural products in domestic markets. They reduce the trade with a tariff of imports decreasing world prices and an export tax increasing them. The tariff raises prices in the importing country by making imported products more expensive. It represents a combined producer subsidy and consumer tax. The export tax represents a producer tax combined with a consumer subsidy in the exporting country.

Subsidies of import and export have opposite effects to trade taxes. World prices are raised by an import sub-

1 Laboratory of Food Marketing, Division of Industrial Organization of Agribusiness, Department of Agricultural and Resource Economics, Graduate School of Bioresource and Bioenvironmental Sciences, Kyushu University

2 Faculty of Business, Marketing and Distribution, Nakamura Gakuen University

* Corresponding author (E-mail: sufukuda@agr.kyushu-u.ac.jp) sidy and it benefits for exporting countries. An export subsidy affects on lowering world prices to the advantages of the importer. Both of them cause disequilibrium condition of international trade. Domestic prices become detach from international prices because of such interventions. Removal of these trade barriers can increase market efficiency and regional integration of markets.

Restrictions of trade impact on producers and consumers directly. Food subsidies and export taxes can hinder production, increase consumption and increase imports. Import tariffs can encourage production, discourage consumption and decrease imports. All policies have negatively effects on both production and consumption. Both producers and consumers lose their economic welfare because allocation of resources is distorted from their efficient utilization by trade restrictions. Economic efficiency of allocation of resources can be enhanced by reducing restrictions of trade with international agreements like GATT.

Subsidies and tariffs trigger more gap between international price and domestic prices. The more the government intervenes in agricultural markets, the more the international trade of agricultural products distorts from the equilibrium conditions. It had experienced market distortions of pulses international trade before 1990 that India strictly controlled on importing of pulses and Myanmar also prohibited and monopolized exporting of pulses until 1988. Socialist agricultural policies in Myanmar (1974-1988) have caused disincentives to farmers for increasing of production. The Indian government's intervention policies have created distorting price signals, inefficient allocation of resources, and shifting comparative advantage away from marginal crops such as pulses towards cereals. This paper scrutinizes the 
impact of market liberalization on international pulses trade.

\section{India Pulses Industry}

India is the largest producer and consumer of the pulses in the world, accounting for 25 percent of global production, 27 percent of consumption, and 34 percent of food use (FAO). It is also top importer, with an 11percent share of world imports during 1995-2001, although imports have only accounted for about 6 percent of domestic consumption during the same period. Pulses are very important crops in India, with annual production of about 13.39 million tones from 22.39 million hectares in 2005. But, the trends of area and production fluctuate year by year depending on climatic and policy conditions (Fig. 1).

Indian government practiced the protection policies throughout the 1970s and 1980s. In the beginning of 1990, government faced the difficulties concerned with trade, economic growth, and a balance of payment crisis. Then, government started the reforms of policy. The reform process included reductions in tariffs and quotas, reductions in import and export restrictions, abolishment of industrial licensing and the floating of exchange rate (WTO-I, 2002).

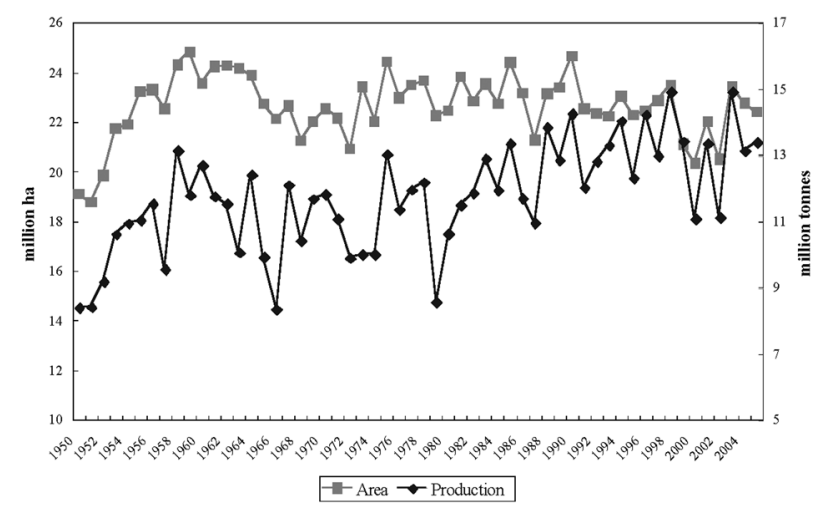

Fig. 1. Trends of Sown Area and Production of Pulses in India.
Tariffs on pulses were reduced gradually and by 1996, all tariffs on pulses were abolished. In the beginning of 2000, tariffs for many agricultural and allied products, such as rice, wheat, millet, sugar, milk powder, apple, chicken, edible oils, etc, were increased. For pulses, import duties were increased from $5 \%$ to $10 \%$ in the Indian Union Budget of 2002-2003 (MANAGE, 2002). Import tariffs and trade policy status of some selected food commodities in India are illustrated in Table 1. In 1991 and 1996, the Indian government restricted the export of pulses although the import was free. Trade of other agricultural products was generally restricted or canalized, i.e. traded under the Public Distribution System.

Over the years, the Indian government's policy has been to protect consumers, especially those on low incomes, by ensuring that prices of most agricultural products are affordable. To achieve this purpose, government set up a Minimum Support Price (MSP) for most agricultural products, including pulses (Agbola, F. W., 2004). Table (2) shows the MSP of selected agricultural commodities in India. The MSP for gram (chickpeas) is about twice the MSP of other agricultural commodities. Although the Indian government supports consumers with MSP for cereals and pulses, there is no significant effect on domestic market price because the MSP for pulses is generally less than the market price. Consequently, domestic pulses production is also hindered and domestic and international market prices are distorted because of the MSP program.

India is the world's largest pulses importer. Black gram, green gram and pigeon pea of Myanmar occupy large shares of imports in India. Importers favor Myanmar because it offers many varieties with qualities similar to those produced in India as well as reasonable prices, low freight rates, and relatively fast delivery. But, the fluctuations of prices and production can make transactions with that country difficult. The data source is from Ministry of Commerce, India (Fig. 2a to Fig. 2c).

Table 1. Import Tariffs and Trade Policy Status of Selected Food Commodities in India

\begin{tabular}{|c|c|c|c|c|c|c|}
\hline \multirow{3}{*}{ Commodity } & \multirow{3}{*}{$\begin{array}{l}\text { Existing Tafiff } \\
\text { April } 1996\end{array}$} & \multirow{3}{*}{$\begin{array}{l}\text { Uruguay } \\
\text { Round } \\
\text { Binding }\end{array}$} & \multicolumn{4}{|c|}{ Trade Policy Status } \\
\hline & & & \multicolumn{2}{|c|}{1991} & \multicolumn{2}{|c|}{1997} \\
\hline & & & Exports & Imports & Exports & Imports \\
\hline Animals & 0 & 100 & Mostly restricted & Mostly restricted & Mostly restricted & Mostly restricted \\
\hline Fresh, chilled and frozen meat & 10 & 150 & Mostly restricted & Restricted & Mostly restricted & Restricted \\
\hline Milk/Cream & 40 & 100 & Restricted & Restricted & Restricted & Restricted \\
\hline Yoghurt & 40 & 100 & & Restricted & & Restricted \\
\hline Rice & 0 & 0 & Mostly restricted & Canalized & Free & Canalized \\
\hline Wheat/Flour & 0 & 100 & Restricted & Canalized & Free & Canalized \\
\hline Pulses & 5 & 100 & Restricted & Free & Restricted & Free \\
\hline Vegetables & 10 & 100 & Mostly Free & Restricted & Mostly Free & Restricted \\
\hline Fruits & 50 & 100 & Mostly Free & Restricted & Mostly Free & Restricted \\
\hline Oilseeds & $40 / 50$ & 100 & Restricted & Canalized & Mostly restricted & Canalized \\
\hline
\end{tabular}

Notes: "Mostly restricted" means that most products or product varieties in the category are subject to licensing or other non-tariff controls.

Source: Adapted from Kelly (1999). 
Table 2. Minimum Support Prices of Various Agricultural Commodities (According to crop year, in Rs. Per Quintal)

\begin{tabular}{lcccccc}
\hline Commodity & Variety & 1998 & 1999 & 2000 & 2001 & 2002 \\
\hline \multirow{2}{*}{ Paddy Rice } & Common & 415 & 440 & 490 & 510 & 530 \\
Maize & Grade "A" & 445 & 470 & 520 & 540 & 560 \\
Wheat & & 360 & 390 & 415 & 445 & 485 \\
Barley & & 510 & 550 & 580 & 610 & 620 \\
Gram & & 350 & 385 & 430 & 500 & 500 \\
\hline
\end{tabular}

Source: Agola, F. W., (2004)

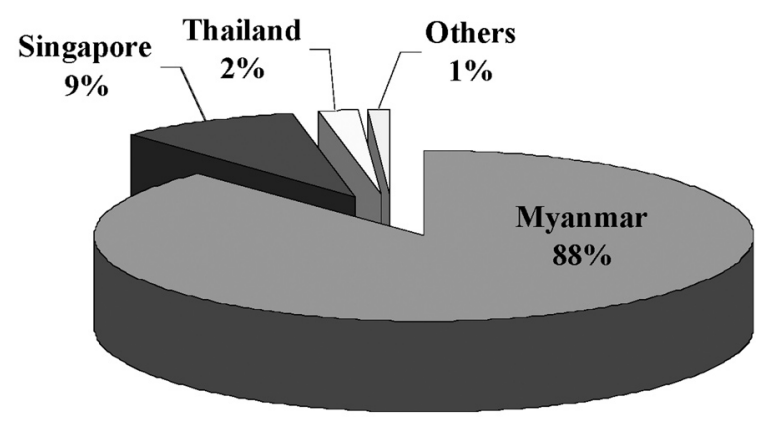

Fig. 2a. Origins of Black Gram Import in India.

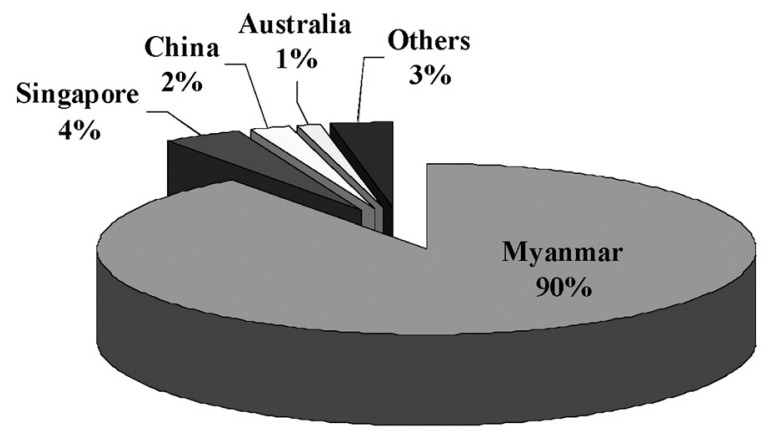

Fig. 2b. Origins of Green Gram Import in India.

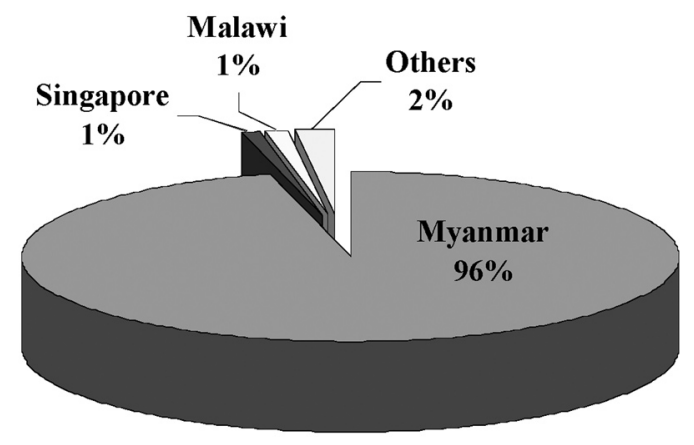

Fig. 2c. Origins of Pigeon Pea Import in India.

\section{Myanmar Pulses Industry}

Before 1988, government had monopolized all agricultural products by Myanmar Export and Import Service under Ministry of Trade and Commerce. After that, domestic markets as well as export markets were liberal- ized for private traders except rice and rice products. Export of pulses was fully liberalized except chickpeas. Chickpea exporters had to sell some portion of export volume to the government at fixed price. Exporter had to pay commercial tax $5 \%$ at their export items until 1998. In 1/1/1999, government imposed the new regulation, 10\% export levy on all agricultural commodities (APO, 1996 and Hla Kyi, 1997).

Destination countries of Myanmar pulse exports are South and South East Asia countries. India is the largest consumer of Myanmar pulses. Share of export to India is large and contributes $71 \%$ in black gram, $60 \%$ in green gram and $93 \%$ in pigeon pea (Fig. 3a to Fig. 3c). Other minor import countries are Indonesia, Pakistan, Singapore, and Malaysia. The data is from Central Statistical Organization, Myanmar, 2005.

Myanmar government has been practicing parallel exchange rate system over long period of time ( $\mathrm{T}$. Ito and M. Kumamoto, 2002). While the official rate has remained pegged to the U.S dollar at around 6 kyat per

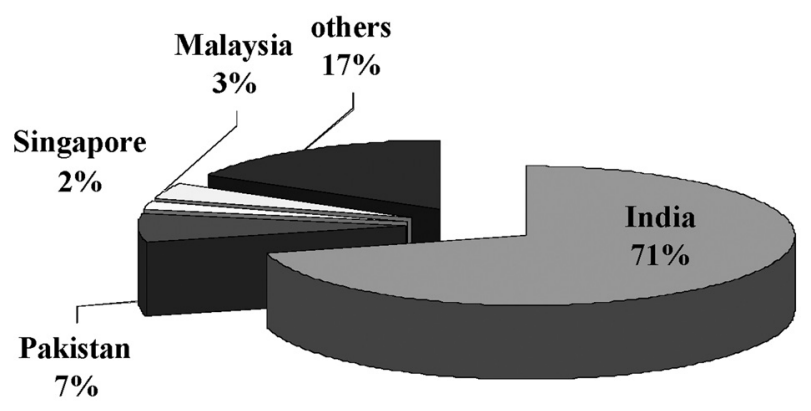

Fig. 3a. Destinations of Black Gram Export in Myanmar (2005).

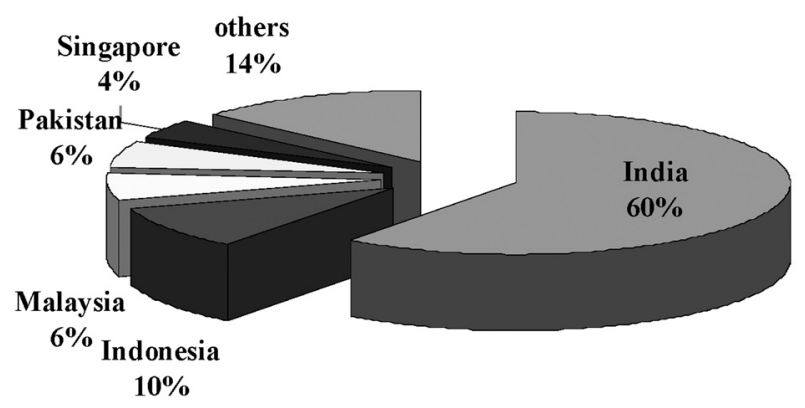

Fig. 3b. Destinations of Green Gram Export in Myanmar (2005). 


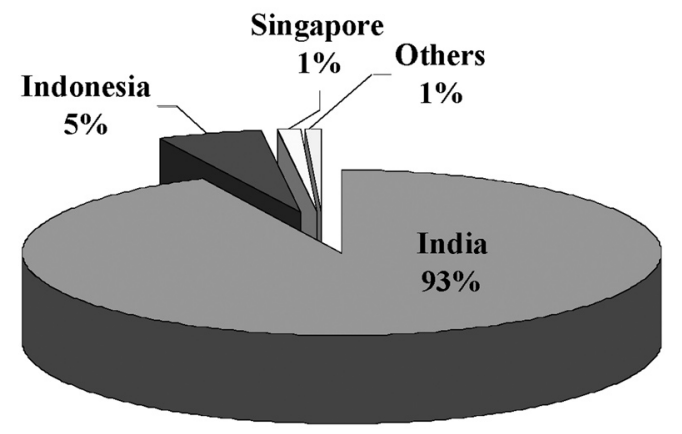

Fig. 3c. Destinations of Pigeon Pea Export in Myanmar (2005).

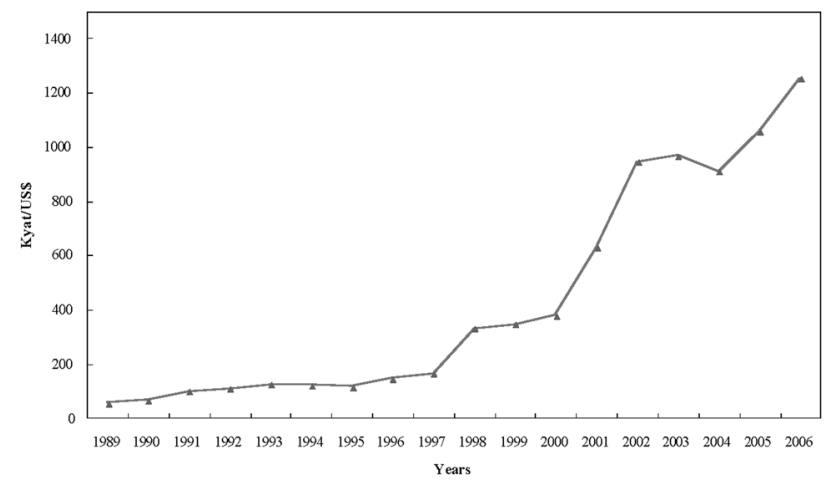

Fig. 4. Fluctuation of Market Exchange Rate in Myanmar.

U.S dollar, the parallel market rate has reached 1200 kyat per U.S dollar at the end of December in 2005 (Fig. 4). Domestic market prices of pulses are determined based on market exchange rate and international prices like New delhi and Mumbi. It causes the distortions of domestic and international prices of pulses. Consequently, exporter is discouraged to expand the exports and foreign reserve become lower and lower, forcing the authorities to tighten controls on imports and so on. The balance of trade is unstable in condition. Unification of exchange rate is an essential way to reduce the inflation rate and price fluctuations, to promote increasing of exports and to integrate domestic markets with global economy.

\section{TRENDS AND DESCRIPTIVE ANALYSIS OF PRICE SERIES OF INTERNATIONAL MARKET}

Trends of prices are illustrated in Fig. 5.a to 5.c. Although the pattern of trends of black gram prices was very similar, the extent of fluctuation of Myanmar prices was higher than India prices.

In green gram, the pattern of the trends was similar between 2000 and 2002. But, the trends differed in some places between 2003 and 2005. Both prices fluctuated over the time and the difference of prices was high. Although the gap of price difference was large, the trends were almost the same in pigeon pea.

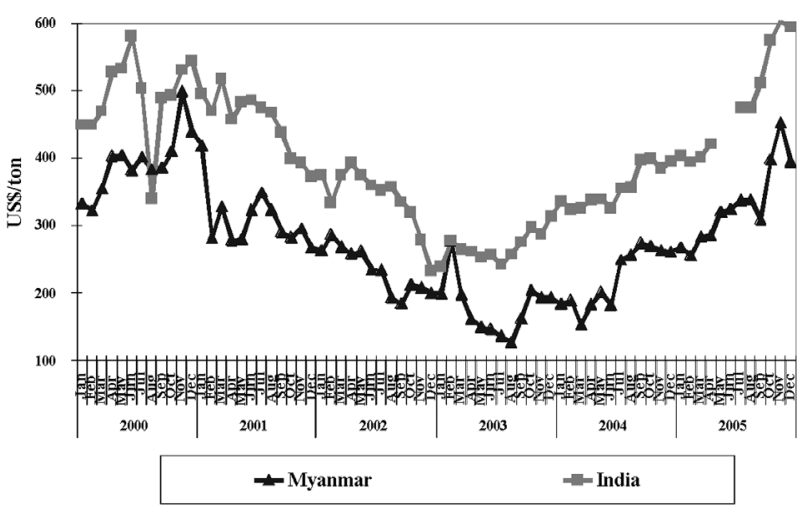

Fig. 5a. Trends of Black Gram Price Series of International Trade.

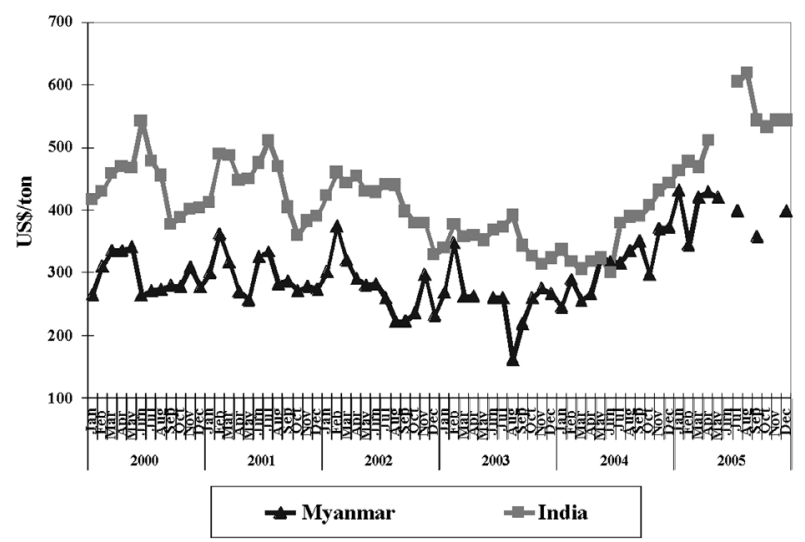

Fig. 5b. Trends of Green Gram Price Series of International Trade.

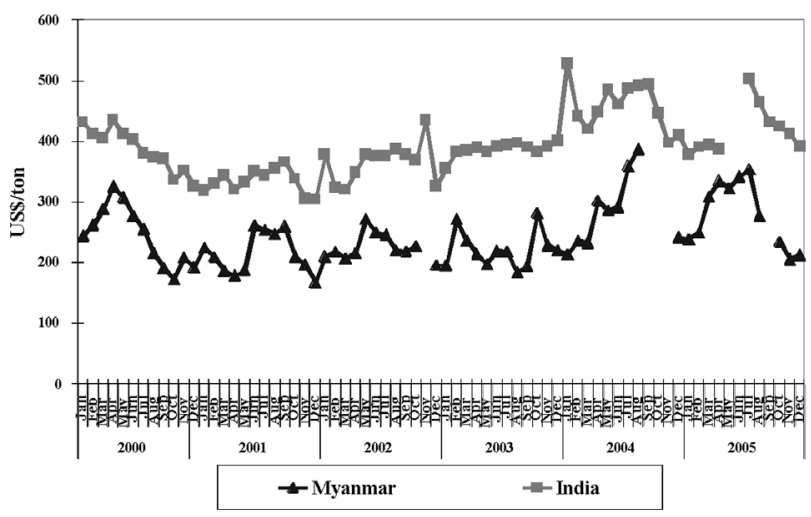

Fig. 5c. Trends of Pigeon Pea Price Series of International Trade.

Descriptive analysis is an effective method for examination of prices at a glance. The results are described in Tables 3.a to 3.c. Coefficient of variation is the measurement of variability of price within the certain period.

In black gram, the variation of price was high and that of Myanmar was higher than that of India. Comparing with black gram, coefficients were low and almost same in both countries of green gram prices. This signal showed well integration of price. In pigeon pea, coefficient of India was smaller than that of Myanmar. It can be concluded that prices in Myanmar fluctuated more than India prices. 
Table 3a. Descriptive Analysis of Black Gram Prices of International Trade

\begin{tabular}{cccccc}
\hline Markets & Mean & Std. Dev. & CV & Minimum & Maximum \\
\hline Myanmar & 278 & 86 & 0.31 & 128 & 499 \\
India & 398 & 96 & 0.24 & 233 & 603 \\
\hline
\end{tabular}

Table 3b. Descriptive Analysis of Green Gram Prices of International Trade

\begin{tabular}{cccccc}
\hline Markets & Mean & Std. Dev. & CV & Minimum & Maximum $\$$ /ton \\
\hline Myanmar & 300 & 53 & 0.18 & 163 & 431 \\
India & 416 & 66 & 0.19 & 301 & 605 \\
\hline
\end{tabular}

Table 3c. Descriptive Analysis of Pigeon Pea Prices of International Trade

\begin{tabular}{cccccc}
\hline Markets & Mean & Std. Dev. & CV & Minimum & Maximum \\
\hline Myanmar & 241 & 47 & 0.2 & 167 & 387 \\
India & 388 & 49 & 0.13 & 305 & 529 \\
\hline
\end{tabular}

\section{TESTING INTEGRATION OF PRICE LINKAGES OF WORLD PULSES TRADE}

Although Asia was dominant on world pulses trade, activities of trade in the region were sluggish before 1990 because there were high import restrictions in India and monopolization of export market in Myanmar. It was the coincidence that India lifted up the restrictions of imports of pulses and Myanmar also liberalized the export market of pulses at the same time. For the great benefits of trade liberalizations, both countries expanded their volume of trades especially in pulses market and became attach international trade. Despite trade liberalization in both countries, there are still many restrictions like minimum support price and export banning of pulses in India and parallel exchange rate and high export taxes in Myanmar. These factors affect strongly on distortion of prices in domestic and international markets and the integration of prices in these markets. It is very imperative to know how the prices in domestic markets transmit their signals to world markets.

Historically, many researchers have used spatial market integration with various methods including correlation analysis, Timmer model, Ravillion model, and co-integration analysis- Engle-Granger methods, Granger causality tests and Johansen multivariate VAR test. This study emphasizes to analyze the integration of pulses prices in India and Myanmar by using Johansen multivariate VAR test and Granger causality test. The objective of the study is to scrutinize whether pulses markets are efficient in international trade after market liberalization.

\section{Johansen's Co-integration Test}

Before co-integration test, it is essential to test the stationary of time series by using augmented DickeyFuller (ADF) test as following equation,

$$
\Delta P_{t}=\rho P_{t-1}+\sum_{i=1}^{p} \delta_{i} \Delta P_{t-1}+e_{t}
$$

The ratio of estimated $\rho$ to their standard errors is the $\mathrm{ADF}$ test statistic. The null hypothesis will be rejected if the estimated value of $\delta$ is negative and significantly different from zero. Johansen's co-integration vectors could be estimated based on following equation,

$$
\begin{aligned}
& \Delta Y_{t}=\mu_{0 t}+\sum_{i=t}^{k-1} \theta_{0 i} \Delta Y_{t-i}+v_{0 t} \\
& Y_{t-k}=\sum_{i=1}^{k-1} \theta_{1 i} \Delta Y_{t-1}+v_{1 t}
\end{aligned}
$$

In equations, $\mathrm{Y}$ is a vector of time series to be examined. The relations of co-integrated series can be identified by using canonical correlation techniques. Trace test and maximal eigen tests will be used for determining the number of co-integration equations. Trace test is given by

$$
\tau_{\text {trace }}=-N \sum_{i=r+1}^{p} \ln \left(1-\Pi_{i}^{2}\right)
$$

Where $\mathrm{N}$ is number of time periods available in the data, $\pi_{\mathrm{k}+1}-----\pi_{\mathrm{n}}$ are the $\mathrm{n}-\mathrm{k}$ smallest canonical corelations of $v_{0 t}$ with respect to $v_{1 t}$. The null hypothesis that there are $\mathrm{k}$ or less co-integration vectors, will be tested by trace test.

The maximal eigen value test uses the $\mathrm{k}+1$ largest squred eigen value. It is given by

$$
\tau_{\max }=-N \ln \left(1-\Pi_{k+1}^{2}\right)
$$

This test evaluates the null hypothesis that there are exactly $\mathrm{k}$ co-integrating vectors in $\mathrm{Y}_{t}$. If both tests' statistics are beyond the critical value, the null hypothesis will be rejected.

\section{Granger Causality Test}

This test examines the causal relationship of variables whether the present of lagged terms of a time series variable $\mathrm{X}$, determine another time series variable $\mathrm{Y}$. The model is specified as follows,

$$
\begin{aligned}
& \Delta P_{i t}=\theta_{11} \Delta P_{i t-1}+\ldots+\theta_{1 n} P_{i t-n}+\theta_{21} \Delta P_{j t-1}+\ldots+\theta_{2 n} \Delta P_{j t-n} \\
& -\gamma_{1}\left(P_{i t-1}-\alpha P_{j t-1}-\delta\right)+\varepsilon_{1 t} \\
& \Delta P_{j t}=\theta_{31} \Delta P_{j t-1}+\ldots+\theta_{3 n} P_{j t-n}+\theta_{41} \Delta P_{i t-1}+\ldots+\theta_{4 n} \Delta P_{i t-n} \\
& -\gamma_{2}\left(P_{i t-1}-\alpha P_{j t-1}-\delta\right)+\varepsilon_{2 t}
\end{aligned}
$$

The following two hypotheses are tested to determine the Granger-Causality relationship between prices

$\theta_{21}=\ldots=\theta_{2 n}=\gamma_{1}=0\left(P_{j}\right.$ does not Granger - cause $\left.P_{i}\right)$ 
$\theta_{41}=\ldots=\theta_{4 n}=\gamma_{2}=0\left(P_{i}\right.$ does not Granger - cause $\left.P_{j}\right)$

F test is carried out for the null hypothesis of no Granger causality. If the F statistic is greater than a certain critical value for $\mathrm{F}$ distribution, the above null hypothesis will be rejected Pulses used in analysis are major exports in Myanmar, Black gram, Green gram and Pigeon pea. Sources of data are Yangon wholesale prices (ready cargo) of pulses for Myanmar from Marketing Information Service and New Delhi wholesale prices of pulses for India from Ministry of Commerce (Economic Time News). Monthly prices were used in analysis from 2000 to 2005.

\section{RESULTS AND DISCUSSIONS}

Testing the stationary is essential for co-integration analysis. All price series were investigated by using the Augmented Dickey Fuller test (ADF) for the presence of a unit root (Tables 4.a to 4.c). The null hypothesis of non stationary in all prices could not be rejected in level. However, the test rejected the null of non stationary in first differences. This indicated that differenced series were stationary and all series were integrated order (1).

In VAR analysis, the suitable lag length was selected based on Akaike Information Criterion (AIC) and Schwarz Criterion (SC) choosing the smallest value. The suitable lag lengths of all pulses were 1-length. The order of integration was tested by using Johansen approach. The results are shown in Tables 5.a to 5.c.

Table 4a. Unit Root Test on Black Gram Price Series of International Trade

\begin{tabular}{|c|c|c|c|c|c|c|c|c|}
\hline \multirow{2}{*}{ Markets } & \multirow{2}{*}{ Obs } & \multicolumn{3}{|c|}{ Unit root-test on price levels } & \multirow{2}{*}{ Obs } & \multicolumn{3}{|c|}{ Unit root-test on first difference } \\
\hline & & $\mathrm{ADF}^{1}$ & $\delta$ & t-value ${ }^{2}$ & & $\mathrm{ADF}^{1}$ & $\delta$ & t-value $e^{2}$ \\
\hline Yangon & 71 & $\mathrm{ADF}(0)$ & -0.081 & -1.607 & 70 & $\operatorname{ADF}(0)$ & -1.127 & -9.189 \\
\hline New Delhi & 68 & $\operatorname{ADF}(0)$ & -0.056 & -1.144 & 66 & $\operatorname{ADF}(0)$ & -1.113 & -8.943 \\
\hline
\end{tabular}

Notes: (1) In the column ADF the number of lags that was allowed for in the unit root test is indicated in brackets, based on the Schwartz criterion. ADF analysis was carried out in Eviews.5.

(2) Critical values are given in MacKinnon: $t=-2.92,5 \%$ level of significance.

Source: Monthly Prices of Black gram from Jan-2000 to Dec-2005.

Market Information Service, Department of Agricultural Planning, Ministry of Agriculture and Irrigation, Myanmar. Economic Times News, Ministry of Commerce, India

Table 4b. Unit Root Test on Green Gram Price Series of International Trade

\begin{tabular}{|c|c|c|c|c|c|c|c|c|}
\hline \multirow{2}{*}{ Markets } & \multirow{2}{*}{ Obs } & \multicolumn{3}{|c|}{ Unit root-test on price levels } & \multirow{2}{*}{ Obs } & \multicolumn{3}{|c|}{ Unit root-test on first difference } \\
\hline & & $\mathrm{ADF}^{1}$ & $\delta$ & t-value ${ }^{2}$ & & $\mathrm{ADF}^{1}$ & $\delta$ & $\mathrm{t}$-value $\mathrm{e}^{2}$ \\
\hline Yangon & 62 & $\operatorname{ADF}(0)$ & -0.304458 & -3.035617 & 58 & $\operatorname{ADF}(0)$ & -1.710114 & -8.687547 \\
\hline New Delhi & 68 & $\operatorname{ADF}(0)$ & -0.117354 & -2.194987 & 66 & $\operatorname{ADF}(0)$ & -0.957152 & -7.580763 \\
\hline
\end{tabular}

Notes: (1) In the column ADF the number of lags that was allowed for in the unit root test is indicated in brackets, based on the Schwartz criterion. ADF analysis was carried out in Eviews.5.

(2) Critical values are given in MacKinnon: $t=-2.92,5 \%$ level of significance.

Source: Monthly Prices of Green gram from Jan-2000 to Dec-2005.

Market Information Service, Department of Agricultural Planning, Ministry of Agriculture and Irrigation, Myanmar.

Economic Times News, Ministry of Commerce, India

Table 4c. Unit Root Test on Pigeon Pea Price Series of International Trade

\begin{tabular}{|c|c|c|c|c|c|c|c|c|}
\hline \multirow{2}{*}{ Markets } & \multirow{2}{*}{ Obs } & \multicolumn{3}{|c|}{ Unit root-test on price levels } & \multirow{2}{*}{ Obs } & \multicolumn{3}{|c|}{ Unit root-test on first difference } \\
\hline & & $\mathrm{ADF}^{1}$ & $\delta$ & t-value ${ }^{2}$ & & $\mathrm{ADF}^{1}$ & $\delta$ & t-value ${ }^{2}$ \\
\hline Yangon & 63 & $\mathrm{ADF}(0)$ & -0.173257 & -1.976272 & 52 & $\mathrm{ADF}(2)$ & -1.228936 & -4.514869 \\
\hline New Delhi & 57 & $\mathrm{ADF}(2)$ & -0.098756 & -1.217378 & 57 & $\operatorname{ADF}(1)$ & -1.704303 & -8.018071 \\
\hline
\end{tabular}

Notes: (1) In the column ADF the number of lags that was allowed for in the unit root test is indicated in brackets, based on the Schwartz criterion. ADF analysis was carried out in Eviews.5.

(2) Critical values are given in MacKinnon: $t=-2.92,5 \%$ level of significance.

Source: Monthly Prices of Pigeon Pea from Jan-2000 to Dec-2005.

Market Information Service, Department of Agricultural Planning, Ministry of Agriculture and Irrigation, Myanmar.

Economic Times News, Ministry of Commerce, India 
Table 5a. Testing for the number of Co-integrating Relations (Black Gram)

\begin{tabular}{|c|c|c|c|c|c|}
\hline $\begin{array}{c}\text { Null } \\
\text { Hypothesis }\end{array}$ & $\begin{array}{l}\text { Alternative } \\
\text { Hypothesis }\end{array}$ & & 95\% Critical Value & 90\% Critical Value & Hypothesized \\
\hline$\lambda$ trace tests & & $\lambda$ trace value & & & No. of CE (s) \\
\hline$r=0$ & $r>0$ & 10.99385 & 12.3209 & 10.47457 & None * \\
\hline$r \leq 1$ & $r>1$ & 0.00273 & 4.1299 & 2.9762 & At most 1 \\
\hline$\lambda$ max tests & & $\lambda$ max value & & & \\
\hline$r=0$ & $r=1$ & 10.99112 & 11.2248 & 9.474804 & None \\
\hline$r=1$ & $r=2$ & 0.00273 & 4.1299 & 2.976163 & At most 1 \\
\hline
\end{tabular}

Notes: If the value of $\lambda$-trace and /or $\lambda$-max exceeds the critical value, we reject the null hypothesis and accept the alternative of more co-integration vectors

Table 5b. Testing for the number of Co-integrating Relations (Green Gram)

\begin{tabular}{|c|c|c|c|c|}
\hline $\begin{array}{c}\text { Null } \\
\text { Hypothesis }\end{array}$ & $\begin{array}{l}\text { Alternative } \\
\text { Hypothesis }\end{array}$ & & 95\% Critical Value & Hypothesized \\
\hline$\lambda$ trace tests & & $\lambda$ trace value & & No. of CE (s) \\
\hline $\mathrm{r}=0$ & $r>0$ & 13.92379 & 12.3209 & None * \\
\hline $\mathrm{r} \leq 1$ & $r>1$ & 0.08314 & 4.1299 & At most 1 \\
\hline$\lambda$ max tests & & $\lambda \max$ value & & \\
\hline$r=0$ & $\mathrm{r}=1$ & 13.84065 & 11.2248 & None \\
\hline $\mathrm{r}=1$ & $r=2$ & 0.0831 & 4.1299 & At most 1 \\
\hline
\end{tabular}

Notes: If the value of $\lambda$-trace and /or $\lambda$-max exceeds the critical value, we reject the null hypothesis and accept the alternative of more co-integration vectors

Table 5c. Testing for the number of Co-integrating Relations (Pigeon pea)

\begin{tabular}{|c|c|c|c|c|c|}
\hline $\begin{array}{c}\text { Null } \\
\text { Hypothesis }\end{array}$ & $\begin{array}{l}\text { Alternative } \\
\text { Hypothesis }\end{array}$ & & 95\% Critical Value & $90 \%$ Critical Value & Hypothesized \\
\hline$\lambda$ trace tests & & $\lambda$ trace value & & & No. of CE (s) \\
\hline $\mathrm{r}=0$ & $r>0$ & 10.27121 & 12.3209 & 10.47457 & None $*$ \\
\hline $\mathrm{r} \leq 1$ & $\mathrm{r}>1$ & 0.26723 & 4.1299 & 2.9762 & At most 1 \\
\hline$\lambda$ max tests & & $\lambda$ max value & & & \\
\hline$r=0$ & $\mathrm{r}=1$ & 10.00398 & 11.2248 & 9.474804 & None \\
\hline $\mathrm{r}=1$ & $\mathrm{r}=2$ & 0.26723 & 4.1299 & 2.9762 & At most 1 \\
\hline
\end{tabular}

Notes: If the value of $\lambda$-trace and /or $\lambda$-max exceeds the critical value, we reject the null hypothesis and accept the alternative of more co-integration vectors

The null of no co-integration vector was rejected in black gram and pigeon pea at 10\% level and in green gram at $5 \%$ level. The degree of market integration was weak.

Long run Integration of Black gram Price of India and Myanmar:

$$
\begin{aligned}
\text { Myanmar }= & 0.699 \text { India } \\
& (25.39)^{* * *}
\end{aligned}
$$

Long run Integration of Green gram Price of India and Myanmar:

$$
\text { Myanmar }=0.72 \text { India }
$$

$$
(27.75)^{* * * *}
$$

Long run Integration of Pigeon pea Price of India and Myanmar:

$$
\begin{aligned}
\text { Myanmar }= & 0.64 \text { India } \\
& (26.44)^{* * *}
\end{aligned}
$$

The long run integration of price series of international markets is shown in equations 10, 11 and 12. The coefficients were relatively small in black gram, green gram and pigeon pea prices of India and Myanmar. Although Myanmar and India were great partners of pulse trade, there was still weak and lack of well connec- 
tion of price linkages because both countries had trade barriers and poor improvement of market accessibility.

Results of short-run integration by VECM are illustrated in Tables 6.a to 6.c. Error correction test is very important to know percent of correction to any deviation in long-run equilibrium price in a single period and the speed of correction of deviations in long-run equilibrium. These coefficients measure the proportional response of a market price to market disequilibrium, which is defined

Table 6a. Estimation of the Dynamic in the Short-run by using VECM (Black Gram)

\begin{tabular}{lcc}
\hline Error Correction: & $\mathrm{D}(\mathrm{IN})$ & $\mathrm{D}(\mathrm{MM})$ \\
\hline CointEq1 & -0.1874 & 0.226093 \\
& -0.11377 & -0.10533 \\
& {$[-1.64716]^{*}$} & {$[2.14650]^{* *}$} \\
\hline
\end{tabular}

Table 6b. Estimation of the Dynamic in the Short-run by using VECM (Green Gram)

\begin{tabular}{lcc}
\hline Error Correction: & $\mathrm{D}(\mathrm{IN})$ & $\mathrm{D}(\mathrm{MM})$ \\
\hline CointEq1 & -0.164289 & 0.088228 \\
& -0.05169 & -0.07266 \\
& {$[-3.17857]^{* * *}$} & {$[1.21432]^{\mathrm{ns}}$} \\
\hline
\end{tabular}

Table 6c. Estimation of the Dynamic in the Short-run by using VECM (Pigeon pea)

\begin{tabular}{lcc}
\hline Error Correction: & D (IN) & D (MM) \\
\hline CointEq1 & -0.34547 & 0.14022 \\
& -0.1398 & -0.12563 \\
& {$[-2.47109]^{* * *}$} & {$[1.11612]^{\text {ns }}$} \\
\hline
\end{tabular}

Table 7a. Granger Causality Test on Black Gram Price Series of International Trade

\begin{tabular}{lcl}
\hline Directions & Lags & F-test \\
\hline $\mathrm{MM} \Rightarrow \mathrm{IN}$ & 9 & $0.886^{\mathrm{ns}}$ \\
$\mathrm{IN} \Rightarrow \mathrm{MM}$ & 9 & $7.057^{* * *}$ \\
\hline
\end{tabular}

Table 7b. Granger Causality Test on Green Gram Price Series of International Trade

\begin{tabular}{lcl}
\hline Directions & Lags & F-test \\
\hline $\mathrm{MM} \Rightarrow \mathrm{IN}$ & 1 & $11.184^{* * * *}$ \\
$\mathrm{IN} \Rightarrow \mathrm{MM}$ & 1 & $0.012^{\text {ns }}$ \\
\hline
\end{tabular}

Table 7c. Granger Causality Test on Pigeon Pea Price Series of International Trade

\begin{tabular}{lcl}
\hline Directions & Lags & F-test \\
\hline MM $\Rightarrow$ IN & 5 & $5.425^{* * *}$ \\
IN $\Rightarrow$ MM & 5 & $1.839^{\text {ns }}$ \\
\hline
\end{tabular}

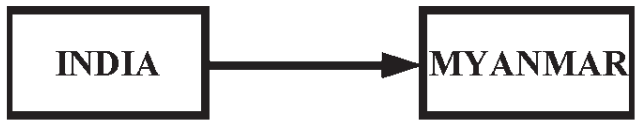

Fig. 6a. Direction of Causality of Black Gram Price of International Trade.

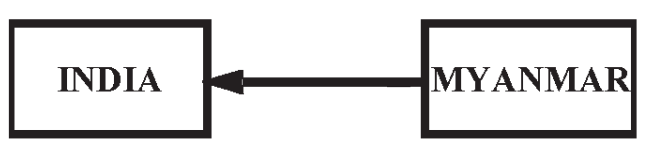

Fig. 6b. Direction of Causality of Green Gram Price of International Trade.

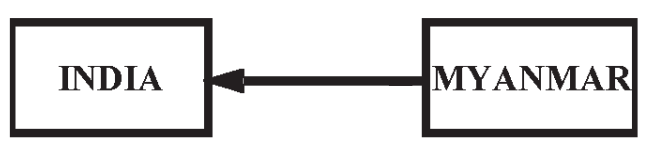

Fig. 6c. Direction of Causality of Pigeon Pea Price of International Trade.

as $1 \%$ divergence in the market price from equilibrium. Stability requires the elasticities to be negative so that a price higher (lower) than equilibrium will cause the price to subsequently fall (rise). India showed significant inelastic and negative responses, with 19\%, 16\% and $35 \%$ of price disequilibrium eliminated in the first month for black gram, green gram and pigeon pea prices. Myanmar showed positive responses in all pulses. Positive equilibrium indicated that prices fluctuated with the movement of time and tended to deviate from the long run equilibrium value for period of time.

The results of Granger causality tests are summarized in Tables 7.a to 7.c and Figures 6.a to 6.c. Myanmar prices Grange caused to all prices of India except black gram. India Granger caused to Myanmar in black gram prices. It can be generally said that Myanmar is a leading country for the formation of international prices. It indicates that international trade of pulses still has asymmetry price transmission and monopolistic behavior.

\section{CONCLUSIONS AND POLICY IMPLICATIONS}

\section{Production and Trade of Pulses}

India will be the world's largest producer and importer of pulses because it is the fast growing economy and steadily increasing population in the world. These two factors influence the production, consumption, and importation of pulses in the country. India has been challenging self-sufficiency supply of pulses because crop competitive of pulses is lower than that of other cereals like rice and wheat. Minimum support prices hinder the growth of production because they are generally below market prices. Government assistance is still low comparing with cereals. The support prices and government procurement programs for wheat and rice are more attractive, encouraging farmers to extend more areas of those crops. 
Myanmar will be also a leading player of pulses' exporter because farmers are encouraged to grow more acreage of pulses with price incentives and it has favorable condition of market like low freight rates and consumer preference of taste in India. Although improvement of varieties and research development are still poor in the country, production of pulses can be increased by cropping intensity like area expanding because most of pulses like black gram and green gram are grown after harvesting of rice and other rainy season crops. The cost of production of pulses is considerably low comparing with other crops. Moreover, the profit of these crops is higher than other crops.

\section{Marketing Efficiency of International Pulses Trade}

Pulses trade is still weak integrated and poor linkages among exporter and importer countries. Although international trade becomes well developed since 1990 because of trade liberalization policy, there are many trade barriers and restrictions in both countries, India and Myanmar. Minimum support price program in India causes distortions of price signals in domestic and international prices. Banning export and high levy of import taxes in India are impediments of marketing efficiency. In Myanmar, parallel exchange rate system and high levy of export taxes are major determinants of spatial efficiency of international markets. Pulses prices of Myanmar fluctuated more than prices of India because short run integration showed positive equilibrium conditions of black gram, green gram and pigeon pea prices of Myanmar while all prices of India had negative equilibrium conditions. This disequilibrium condition may be the results of high inflation and parallel exchange rate system. These systems have negative impact on price fluctuations and export promotion.

Granger causality tests revealed the existence of a unidirectional causal relationship, whereby green gram and pigeon pea of Myanmar Granger-caused those prices in India and black gram prices of India Grangercaused prices in Myanmar one way direction. This imperfect and asymmetry price transmission may be the results of quantitative restrictions of trade, misalignment exchange rate system and high levy of export and import taxes in pulses trade.

It is essential the removal of impediments of international trade that will be beneficial domestic markets as well as international markets by improving pricing efficiency. Instead of minimum support price program (MSP), an alternative policy should be implemented by Indian government for poor consumers through the provision of a subsidy at the consumption level. This will reduce government's expenditures and fluctuations of price. Government should encourage export liberalization of pulses. This will induce the production and export of pulses. Myanmar government should endeavor the unification system of exchange rate system to reduce inflation rate and fluctuation of prices. This will reduce budget deficits and encourage exporters more exports. Government should reduce export taxes as much as possible until abolishing to promote the production and exports of agricultural products. Both governments should try lifting up restrictions and barriers of trade to take the advantage of fruitful opportunities of trade for their nations.

\section{REFERENCES}

APO 1996 Agricultural Trade Policy in Asia-Pacific, Asian Productivity Organization, Tokyo

Agbola, F. W., 2004 Agricultural Policy Reform in India: Implications for Pulse Trade, Prices and Production, 1970-1999, Agribusiness Perspectives, 63: ISSN 1442-6951

Agbola, F. W., Kelley, T. G., Bent, M. J. and P. Rao, P. 2002 Chickpea marketing in India: Challenges and Opportunities, Agribusiness Perspectives, 53: ISSN 1442-6951

Agbola, F. W. and Damoense, M. Y. 2005 Time-series estimation of import demand function for pulses in India. Journal of Economic Studies, 32(2): 146-157

C. Peter. Timmer 1986 Getting prices right : the scope and limits of agricultural price policy Cornell University Press, USA

Dickey, D. A., and W. A. Fuller 1979 Distribution of the Estimators for Autoregressive Time Series with a Unit Root. Journal of the American Statistical Association, 79: 427-431

Dickey, D. A., and W. A. Fuller 1981 Likelihood Ratio Statistics for Autoregressive Time Series in a Unit Root. Econometica, 49: $1057-1072$

Du Yang 2002 Levels and Determinants of Agricultural Market Integration: The Impacts of Policies on Marketisation. Working Paper, CEP02-2, Asia Pacific School of Economics and Management, Australian National University, Australia

Engle, R. F. and Granger, C. W. J. 1987 Cointegration and error correction: representation, estimation and testing. Econometrica, 55: 251-276

Food and Agricultural Organization (FAO) 2000 Agricultural Marketing in Myanmar. Ministry of Agriculture and Irrigation, Yangon

Granger, C. W. J. 1969 Investigating Causal Relationships by Econometric Models and Cross Spectral Methods. Econometrica, 37: 424-438

Hla Kyi 1997 Production, consumption and marketing of selected pulses in Myanmar. Yangon, Myanmar

Hla Kyi et al. 1997 Market Prospects for Pulses in South Asia: International and Domestic Trade. CGPRT centre, Indonesia

Johansen, S. and Juselius, K. 1990 Maximum Likelihood Estimation and Inference on Cointegration. Oxford Bulletin of Economics and Statistics, 52(2): 169-210

Johansen, S. 1991 Estimation and Hypothesis Testing of Cointegration Vectors in Gaussian Vector Autoregressive Models. Econometrica, 56(6): 1551-1580

Luu Thanh Duc Hai 2003 Rice Markets in the Mekong River Delta, Vietnam: A market integration analysis. CAS Discussion Paper, 40, Center for ASEAN Studies. Catho University, Catho, Vietnam

MANGE 2002 WTO and Agriculture, Focus: Pulses. National Institute of Agricultural Extension Management, Academy of Business Studies, India

Ravillion, M. 1986 Testing Marketing Integration. American Journal of Agricultural Economics, 68(2): 292-307

Takatoshi ITO and Masao KUMAMOTO 2002 Money, Inflation and Exchange Rate in Myanmar, In "Economic Transition in Myanmar After 1988", edited by Koichi FUJOTA et al., Institute of Developing Economies, Tokyo

Walter Enders 1995 Applied Econometric Time Series. John Wiley \& Sons, Inc., U.S.A

WTO-I 2002 Trade Policy Reviews-India. World Trade Organization, Geneva, Switzerland

Yoon Hoseop and Huh Gilhaeng 2003 Policy Directions of Agricultural Marketing in the Union of Myanmar. Journal of Rural Development, 26: $67-97$ 